\title{
Elevated preoperative neutrophil/ lymphocyte ratio is associated with poor prognosis in soft-tissue sarcoma patients
}

\author{
J Szkandera ${ }^{1}$, G Absenger ${ }^{1}$, B Liegl-Atzwanger ${ }^{2}$, M Pichler ${ }^{1}$, M Stotz ${ }^{1}, \mathrm{H} \mathrm{Samonigg}^{1}, \mathrm{M}$ Glehr $^{3}, \mathrm{M} \mathrm{Zacherl}^{3}$, \\ T Stojakovic $^{4}$, A Gerger ${ }^{\star, 1,5}$ and A Leithner ${ }^{3}$ \\ ${ }^{1}$ Division of Clinical Oncology, Department of Medicine, Medical University of Graz, Auenbruggerplatz 15, 8036 Graz, Austria; \\ ${ }^{2}$ Institute of Pathology, Medical University of Graz, Auenbruggerplatz 25, $8036 \mathrm{Graz}$, Austria; ${ }^{3}$ Department of Orthopaedic Surgery, \\ Medical University of Graz, Auenbruggerplatz 5, $8036 \mathrm{Graz}$, Austria; ${ }^{4}$ Clinical Institute of Medical and Chemical Laboratory \\ Diagnostics, Medical University of Graz, Auenbruggerplatz 15, 8036 Graz, Austria and ${ }^{5}$ Research Unit Genetic Epidemiology and \\ Pharmacogenetics, Division of Clinical Oncology, Department of Medicine, Medical University of Graz, Auenbruggerplatz 15, 8036 \\ Graz, Austria
}

Background: Recent data indicate that tumour microenvironment, which is influenced by inflammatory cells, has a crucial role in cancer progression and clinical outcome of patients. In the present study, we investigated the prognostic relevance of preoperative neutrophil/lymphocyte (N/L) ratio on time to tumour recurrence (TTR) and overall survival (OS) in soft-tissue sarcoma (STS) patients who underwent curative surgical resection.

Methods: In all, 260 STS patients were included in this retrospective study. Kaplan-Meier curves and multivariate Cox proportional models were calculated for TTR and OS.

Results: In univariate analysis, elevated N/L ratio was significantly associated with decreased TTR (hazard ratio (HR), 2.32; $95 \%$ confidence interval $(\mathrm{Cl}), 1.30-4.14 ; P=0.005)$ and remained significant in the multivariate analysis $(\mathrm{HR}, 1.98 ; 95 \% \mathrm{Cl}, 1.05-3.71$; $P=0.035$ ). Patients with elevated N/L ratio showed a median TTR of 77.9 months. In contrast, patients with low N/L ratio had a median TTR of 99.1 months. Regarding OS, elevated N/L ratio was also significantly associated with decreased survival in univariate analysis $(\mathrm{HR}, 2.90 ; 95 \% \mathrm{Cl}, 1.82-4.61 ; P=0.001)$ and remained significant in multivariate analysis $(\mathrm{HR}, 1.88 ; 95 \% \mathrm{Cl}$, 1.14-3.12; $P=0.014)$.

Conclusion: In conclusion, our findings suggest that an elevated preoperative N/L ratio predicts poor clinical outcome in STS patients and may serve as a cost-effective and broadly available independent prognostic biomarker.

Soft-tissue sarcomas (STS) represent a complex group of neoplasms of mesenchymal origin with an incidence of about $1 \%$ among all human malignancies (Siegel et al, 2012). The clinical implications of STS are disproportional to their frequency, and their medical management is challenging (Borden et al, 2003). Despite several improvements in early diagnosis, surgical techniques, and radio- and chemotherapy, this disease remains a threat to life for many patients. The high mortality is related to tumour progression and complications of distant metastasis. Currently, the prediction of disease progression is limited to the use of clinical and histopathological factors, including age at diagnosis, tumour size, histologic grade, histologic subtype, tumour depth, tumour site, and margin status (Kattan et al, 2002). New prognostic markers are needed to allow a strategy for stratifying patients with STS for risk of tumour recurrence to provide individual adjuvant therapy and follow-up schedules. Various molecular biomarkers 
have been intensively investigated to predict clinical outcome in cancer patients, but excessive costs and technical factors preclude their clinical use (Chen et al, 2012; Gousias et al, 2012; Zhang et al, 2012).

Recent data indicate that inflammatory cells that accumulate around neoplasms (e.g., in oesophageal, gastric, colorectal, cervical, ovarian, bladder, pancreatic, prostate, and non-small cell lung cancer) have a crucial role in tumour progression and its prognosis (Coussens and Werb, 2002; Mantovani et al, 2008). For example, patients with a high density of lymphocytes in the stroma of tumours were reported to have a better clinical outcome compared with those with a low density of lymphocytes, whereas a high density of neutrophils was associated with poor clinical outcome (Clark et al, 2007; Teramukai et al, 2009). The systemic inflammatory response also causes changes in the levels of circulating white blood cells, including neutrophils and lymphocytes. However, day-dependent fluctuations in the number of neutrophils are not always in line with those of lymphocytes (Suzuki et al, 1997). Hence, the relative value of a combined index using neutrophil and lymphocyte counts in form of a neutrophil to lymphocyte $(\mathrm{N} / \mathrm{L})$ ratio can more accurately reflect fluctuations between neutrophils and lymphocytes to reflect the antitumour efficacy of the host immune system more precisely. To date, N/L ratio was identified as a prognostic marker in many types of cancer including gastrointestinal tract malignancies, non-small cell lung cancer, cervical carcinoma, hepatocellular carcinoma, pancreatic and ovarian cancer, showing a consistently decreased survival in patients presenting with a high N/L ratio (Gomez et al, 2008; Cho et al, 2009; Sarraf et al, 2009; An et al, 2010; Jung et al, 2011; Lee et al, 2012; Mallappa et al, 2012). However, there is little information on the influence of the preoperative N/L ratio on clinical outcome in STS patients (Idowu et al, 2012). Predicting survival of cancer patients by determining the N/L ratio, which can be measured relatively simple and cost-effective from peripheral blood, might be helpful in patient stratification and individual risk assessment.

The aim of the current study was to assess the predictive value of preoperative N/L ratio for time to tumour recurrence (TTR) and overall survival (OS) in a large cohort of STS patients with curative surgical resection.

\section{MATERIALS AND METHODS}

Subjects. In all, 260 patients with histologically confirmed STS, which have been operated between March 1998 and November 2010 at the Department of Orthopaedic Surgery, Medical University of Graz, were included in this retrospective study. Follow-up was performed until November 2012. All patients were included in the follow-up programme of the Department of Orthopaedic Surgery and the Division of Clinical Oncology, Department of Medicine, Medical University of Graz, providing follow-up examinations in regular intervals (3-month intervals in years 1-3, 6-months intervals in years $4-5$, and 12-month intervals in years 6-15 after diagnosis). Follow-up investigations included clinical check-up and radiological analyses (computed tomography, magnetic resonance imaging, abdominal ultrasound, chest $\mathrm{X}$-ray, or computed tomography). Follow-up data of all patients were available.

Clinical information including treatment scheme (surgery, radio- and chemotherapy) and histopathological diagnosis including tumour grade were retrospectively obtained from the patient's history. Surgical margins were determined as wide or marginal according to Enneking et al (1980). For the present study, all histologic specimens were centrally re-reviewed by an independent experienced pathologist (BL-A) specialised in diagnosing STS at the Institute of Pathology, Medical University of Graz. All sarcomas were diagnosed according to the current WHO classification soft tissue and bone tumours (Fletcher et al, 2002). Tumours were graded according to the French Federation of Cancer Centres Sarcoma Group (FNCLCC) grading system (Coindre, 2006) or tumour grade was defined by tumour entity. Malignant fibrous histiocytomas have been re-classified according to the current diagnostic criteria (Fletcher et al, 2002; Liegl-Atzwanger et al, 2009).

This study has been approved by the Institutional Review Board (IRB) of the Medical University of Graz (25-050 ex 12/13).

Statistical analysis. The primary end point of the study was TTR. Time to tumour recurrence was calculated from the date of diagnosis of STS to the date of the first observation of tumour recurrence. It was censored at the time of death or at the last follow-up if the patient remained tumour recurrence-free at that time. The secondary end point was OS. Overall survival was determined from the date of diagnosis to the date of death of any cause. The optimal cutoff values for the N/L ratio were calculated by applying receiver operating curve (ROC) analysis.

The N/L ratio was correlated with clinical and histopathological data by chi square $\left(\chi^{2}\right)$ test. The association between clinical and histopathological parameters and N/L ratio with TTR and OS was analysed using Kaplan-Meier curves and compared by the logrank test. In the multivariate Cox-regression analysis, the model was adjusted for prognostic factors significantly associated with end points in univariate analysis. Hazard ratios (HRs) estimated from the Cox analysis were reported as relative risks with corresponding 95\% confidence intervals (CIs). All analyses were performed using the SPSS statistical software package (SPSS Inc., Sunnyvale, CA, USA). A two-sided $P<0.05$ was considered as statistically significant.

\section{RESULTS}

Baseline patient characteristics, tumour biological factors, and therapy modalities are shown in Table 1 . The median age at time of diagnosis was 59 years (range 18-96 years). The median follow-up time was 50 months (range $0-120$ months (censored)). The included histologic diagnoses are summarised in Table 2. Applying ROC analysis the optimal cutoff value for N/L ratio was 3.45 for TTR (AUC: $0.616,95 \% \mathrm{CI}=0.547-0.677$ ) and 3.58 for OS (AUC: $0.676,95 \% \mathrm{CI}=0.611-0.736$ ).

In univariate analysis, we found a significant association between tumour grade, tumour necrosis and adjuvant radio- and chemotherapy and TTR and between tumour grade, tumour necrosis, tumour stage and adjuvant chemotherapy and OS (Tables 3 and 4). In multivariate analysis, we observed a significant association between tumour necrosis and adjuvant chemotherapy and TTR and between tumour necrosis and tumour stage and OS (Tables 3 and 4).

An elevated N/L ratio was significantly associated with tumour size $\geqslant 5 \mathrm{~cm}$ and the presence of histopathological tumour necrosis ( $P=0.019$ and $P=0.001)$, respectively. None of the other clinicopathological parameters was associated with an N/L ratio of $\geqslant 3.45$ (data not shown).

Of the 260 STS patients, $9(3.5 \%)$ were metastasised at diagnosis and $41(15.8 \%)$ developed metastatic disease within 10 years follow-up period. Eighty-six (33.1\%) patients died within 10 years follow-up period. Among the 260 STS patients, metastatic disease was diagnosed in 23 of $148(15.5 \%)$ patients with an N/L ratio of $<3.45$ and in 23 of $80(28.8 \%)$ patients with an N/L ratio of $\geqslant 3.45$ $(P<0.018)$. Regarding OS, death occurred in 35 of $156(22.4 \%)$ patients with N/L ratio $<3.58$ and in 37 of $72(51.4 \%)$ patients with $\mathrm{N} / \mathrm{L}$ ratio $\geqslant 3.58(P<0.001)$. 


\begin{tabular}{|c|c|c|}
\hline & $N$ & $\%$ \\
\hline \multicolumn{3}{|l|}{ Sex } \\
\hline Male & 141 & 54.2 \\
\hline Female & 119 & 45.8 \\
\hline \multicolumn{3}{|l|}{ Tumour site } \\
\hline Trunk & 24 & 9.2 \\
\hline Extremities & 236 & 90.8 \\
\hline \multicolumn{3}{|l|}{ Tumour grade } \\
\hline G1 & 43 & 16.5 \\
\hline $\mathrm{G} 2$ & 54 & 20.8 \\
\hline G3 & 161 & 61.9 \\
\hline Unknown & 2 & 0.8 \\
\hline \multicolumn{3}{|l|}{ Tumour size } \\
\hline$>5$ & 174 & 66.9 \\
\hline$\leqslant 5$ & 63 & 24.2 \\
\hline Unknown & 23 & 8.8 \\
\hline \multicolumn{3}{|l|}{ Tumour depth } \\
\hline Superficial & 65 & 25 \\
\hline Deep & 185 & 71.2 \\
\hline Unknown & 10 & 3.8 \\
\hline \multicolumn{3}{|l|}{ Tumour necrosis } \\
\hline None & 112 & 43.1 \\
\hline$<50 \%$ & 86 & 33.1 \\
\hline$\geqslant 50 \%$ & 59 & 22.7 \\
\hline Unknown & 3 & 1.2 \\
\hline \multicolumn{3}{|l|}{ Surgical margins } \\
\hline Wide & 242 & 93.1 \\
\hline Marginal & 18 & 6.9 \\
\hline \multicolumn{3}{|l|}{ Tumour stage } \\
\hline Localised at diagnosis & 251 & 96.5 \\
\hline Metastasised at diagnosis & 9 & 3.5 \\
\hline \multicolumn{3}{|l|}{ Adjuvant radiotherapy } \\
\hline Yes & 167 & 64.2 \\
\hline No & 89 & 34.2 \\
\hline Unknown & 4 & 1.5 \\
\hline \multicolumn{3}{|l|}{ Adjuvant chemotherapy } \\
\hline Yes & 35 & 13.5 \\
\hline No & 218 & 83.8 \\
\hline Unknown & 7 & 2.7 \\
\hline
\end{tabular}

In univariate analysis, elevated preoperative $\mathrm{N} / \mathrm{L}$ ratio was significantly associated with decreased TTR (HR, 2.32; 95\%CI, 1.30-4.14; $P=0.005$ ) (Table 3; Figure 1) and remained significant in the multivariate analysis including tumour grade, tumour necrosis, and adjuvant radio- and chemotherapy (HR, 1.98; 95\%CI, $1.05-3.71 ; P=0.035$ ) (Table 3 ). Patients with $\mathrm{N} / \mathrm{L}$ ratio $\geqslant 3.45$ showed a median TTR of 77.9 months. In contrast, patients with $\mathrm{N} / \mathrm{L}$ ratio $<3.45$ had a median TTR of 99.1 months. In univariate analysis, elevated N/L ratio was also significantly associated with decreased OS (HR, 2.90; 95\%CI, 1.82-4.61; $P=0.001$ ) (Table 4,
Table 2. Histologic type

\begin{tabular}{|l|c|c|}
\hline \multicolumn{2}{|l|}{ N } & $\%$ \\
\hline Myxofibrosarcoma & 76 & 29.2 \\
\hline Liposarcoma & 26 & 10 \\
\hline Well differentiated & 20 & 7.7 \\
Myxoid & 13 & 5 \\
Pleomorphic & 32 & 12.3 \\
\hline Leiomyosarcoma & 28 & 10.8 \\
\hline Synovial sarcoma & 19 & 7.3 \\
\hline Pleomorphic sarcoma & 10 & 3.8 \\
\hline Malignant peripheral nerve sheath tumour & 8 & 3.1 \\
\hline Spindle cell sarcoma NOS & 8 & 3.1 \\
\hline Epithelioid sarcoma & 6 & 2.3 \\
\hline Dermatofibrosarcoma protuberans & 4 & 1.5 \\
\hline Pleomorphic rhabdomyosarcoma & 3 & 1.2 \\
\hline Angiosarcoma & 2 & 0.8 \\
\hline Fibrosarcoma & 2 & 0.8 \\
\hline Myxoid chondrosarcoma & 2 & 0.8 \\
\hline Malignant mesenchymoma & 1 & 0.4 \\
\hline Alveolar soft part sarcoma & & \\
\hline Abbreviation: N=number; NOS =not otherwise specified. & & \\
\hline
\end{tabular}

Figure 2) and remained significant in multivariate analysis including tumour grade, tumour stage, tumour necrosis, and adjuvant chemotherapy (HR, 1.88; 95\%CI, 1.14-3.12; $P=0.014$ ) (Table 4). Patients with $\mathrm{N} / \mathrm{L}$ ratio $\geqslant 3.58$ presented with a median OS of 60.5 months, whereas patients with $\mathrm{N} / \mathrm{L}$ ratio $<3.58$ showed a median OS of 93.2 months.

In subgroup analyses of the four major histologic types (myxofibrosarcoma, liposarcoma, leiomyosarcoma, and synovial sarcoma), we found a significant association between elevated N/L ratio and decreased TTR in myxofibrosarcoma and between elevated N/L ratio and decreased OS in myxofibrosarcoma and liposarcoma in univariate analysis (Tables 5 and 6). In multivariate analysis, the result remained statistically significant for liposarcoma and OS (Table 6).

\section{DISCUSSION}

In the present study, we showed that elevated preoperative $\mathrm{N} / \mathrm{L}$ ratio in the peripheral blood is associated with decreased TTR and OS in STS patients following curative surgery.

It has been widely established that the ability of tumours to progress and metastasize is not only dependent on the intrinsic characteristics of tumour cells, but also on the tumour microenvironment. The tumour environment that is influenced by inflammatory cells including leukocytes is responsible for the inflammatory response and supports proliferation, survival, and migration of tumour cells through the inhibition of apoptosis, promotion of angiogenesis, and damage of DNA (Jackson et al, 1997; Jaiswal et al, 2000; Coussens and Werb, 2002; Mantovani et al, 2008). The systemic inflammatory reaction results in neutrophilia and relative lymphocytopenia, measurable in the peripheral blood (Jilma et al, 1999; Clark et al, 2007; Teramukai et al, 2009). In recent years, there has been increasing evidence that high $\mathrm{N} / \mathrm{L}$ ratio correlates with poor clinical outcome in patients 
Table 3. Univariate and multivariate analysis of association of prognostic factors and $\mathrm{N} / \mathrm{L}$ ratio with time to tumour recurrence

Univariate analysis

Multivariate analysis

\begin{tabular}{l|c|c|c|c|}
\hline Parameter & HR (95\% Cl) & P-value & HR (95\% Cl) & -value \\
\hline Sex & $\begin{array}{l}1 \text { (referent) } \\
1.165(0.66-2.04)\end{array}$ & 0.593 & 1 (referent) \\
\hline $\begin{array}{l}\text { Female } \\
\text { Male }\end{array}$ & & $0.57-1.85)$ & 0.924 \\
\hline
\end{tabular}

Tumour site

Extremities

Trunk

1 (referent)

0.827

1 (referent)

$1.42(0.63-3.20)$

0.400

Tumour depth

Superficial

Deep

1 (referent)

$1.01(0.52-1.94)$

0.987

1 (referent)

$0.85(0.44-1.66)$

0.636

Tumour grade

\begin{tabular}{l|c|r|r} 
G1 & 1 (referent) & 0.040 & 1 (referent) \\
G2 & $0.16(0.04-0.67)$ & & $3.81(0.80-18.11)$ \\
G3 & $1.00(0.54-1.88)$ & $2.37(0.51-11.02)$
\end{tabular}

Tumour size

\begin{tabular}{l|c|r|r}
$<5 \mathrm{~cm}$ & 1 (referent) & 0.169 & 1 (referent) \\
$\geqslant 5 \mathrm{~cm}$ & $1.67(0.81-3.50)$ & & $1.47(0.69-3.12)$
\end{tabular}

Tumour necrosis

0

$\leqslant 50 \%$

$>50 \%$

1 (referent)

$2.67(1.32-5.41)$

$3.99(1.88-8.46)$

0.001

1 (referent)

$1.96(0.95-4.04)$

$3.00(1.28-7.01)$

\section{Resection margins}

\begin{tabular}{l|c} 
Wide & 1 (referent) \\
Marginal & $1.02(0.37-2.83)$
\end{tabular}

0.971

1 (referent)

$1.29(0.44-3.78)$

0.156

Marginal

$1.02(0.37-2.83)$

NA

NA

Localised at diagnosis

Metastasised at diagnosis

NA

NA

0.322

Adjuvant chemotherapy

Yes
No

1 (referent)

3.01 (1.69-5.39)

$<0.001$

1 (referent)

$1.16(0.55-2.44)$

Adjuvant radiotherapy

Yes

No

1 (referent)

$1.97(1.01-3.86)$

0.047

1 (referent)

$1.16(0.55-2.44)$

0.037

$\mathrm{N} / \mathrm{L}$ ratio 3.45

$<3.45$

$\geqslant 3.45$

1 (referent)

2.32 (1.30-4.14)

0.005

1 (referent)

1.98 (1.05-3.71)

0.637

Abbreviations: $\mathrm{Cl}=$ confidence interval; $\mathrm{HR}=$ hazard ratio; $\mathrm{NA}=$ not applicable; $\mathrm{N} / \mathrm{L}=$ neutrophil/lymphocyte.

with various cancers after tumour resection. In colorectal cancer, increased preoperative $\mathrm{N} / \mathrm{L}$ ratio was identified as an independent factor predicting tumour recurrence following curative surgery (Mallappa et al, 2012). Sarraf et al (2009) reported that an increased preoperative $\mathrm{N} / \mathrm{L}$ ratio was associated with higher tumour stage and remained an independent predictor of survival after complete resection for primary lung cancer. In uterine sarcomas, the N/L ratio was shown to be more useful than serum CA 125 for the preoperative differentiation of uterine sarcomas from benign tumours (Kim et al, 2010). Cho et al (2009) observed that an elevated N/L ratio may predict an adverse outcome in ovarian cancer. In STS, only one study indicated an association between the N/L ratio and disease-specific outcome, suggesting worse outcome in patients with elevated pretreatment N/L ratio. This study, however, included only 83 STS patients, had a relative short follow-up period and analysed only OS, which might be influenced by other non-tumour related factors, as the main clinical end point (Idowu et al, 2012). 
Table 4. Univariate and multivariate analysis of association of prognostic factors and $N / L$ ratio with overall survival

\begin{tabular}{|c|c|c|c|c|}
\hline \multirow[b]{2}{*}{ Parameter } & \multicolumn{2}{|c|}{ Univariate analysis } & \multicolumn{2}{|c|}{ Multivariate analysis } \\
\hline & $\mathrm{HR}(95 \% \mathrm{Cl})$ & $\boldsymbol{P}$-value & HR (95\% Cl) & $\boldsymbol{P}$-value \\
\hline \multicolumn{5}{|l|}{ Sex } \\
\hline $\begin{array}{l}\text { Female } \\
\text { Male }\end{array}$ & $\begin{array}{c}1 \text { (referent) } \\
0.82(0.53-1.26)\end{array}$ & 0.364 & $\begin{array}{c}1 \text { (referent) } \\
0.62(0.39-0.97)\end{array}$ & 0.035 \\
\hline \multicolumn{5}{|l|}{ Tumour site } \\
\hline $\begin{array}{l}\text { Extremities } \\
\text { Trunk }\end{array}$ & $\begin{array}{c}1 \text { (referent) } \\
1.05(0.54-2.04)\end{array}$ & 0.877 & $\begin{array}{c}1 \text { (referent) } \\
1.21(0.62-2.35)\end{array}$ & 0.592 \\
\hline \multicolumn{5}{|l|}{ Tumour depth } \\
\hline $\begin{array}{l}\text { Superficial } \\
\text { Deep }\end{array}$ & $\begin{array}{c}1 \text { (referent) } \\
1.00(0.60-1.65)\end{array}$ & 0.986 & $\begin{array}{c}1 \text { (referent) } \\
0.88(0.53-1.49)\end{array}$ & 0.632 \\
\hline \multicolumn{5}{|l|}{ Tumour grade } \\
\hline $\begin{array}{l}\text { G1 } \\
\text { G2 } \\
\text { G3 }\end{array}$ & $\begin{array}{c}1 \text { (referent) } \\
2.06(0.72-5.84) \\
5.78(2.32-14.41)\end{array}$ & $<0.001$ & $\begin{array}{c}1 \text { (referent) } \\
1.98(0.60-6.59) \\
2.66(0.84-8.47)\end{array}$ & 0.098 \\
\hline \multicolumn{5}{|l|}{ Tumour size } \\
\hline $\begin{array}{l}<5 \mathrm{~cm} \\
\geqslant 5 \mathrm{~cm}\end{array}$ & $\begin{array}{c}1 \text { (referent) } \\
1.35(0.78-2.35)\end{array}$ & 0.282 & $\begin{array}{c}1 \text { (referent) } \\
1.29(0.73-2.27)\end{array}$ & 0.381 \\
\hline \multicolumn{5}{|l|}{ Tumour necrosis } \\
\hline $\begin{array}{l}0 \\
\leqslant 50 \% \\
>50 \%\end{array}$ & $\begin{array}{c}1 \text { (referent) } \\
2.42(1.34-4.40) \\
6.02(3.36-10.78)\end{array}$ & $<0.001$ & $\begin{array}{c}1 \text { (referent) } \\
1.47(0.73-2.95) \\
3.00(1.40-6.45)\end{array}$ & 0.001 \\
\hline \multicolumn{5}{|l|}{ Resection margins } \\
\hline $\begin{array}{l}\text { Wide } \\
\text { Marginal }\end{array}$ & $\begin{array}{c}1 \text { (referent) } \\
0.90(0.36-2.22)\end{array}$ & 0.811 & $\begin{array}{c}1 \text { (referent) } \\
1.09(0.43-2.76)\end{array}$ & 0.850 \\
\hline \multicolumn{5}{|l|}{ Tumour stage } \\
\hline $\begin{array}{l}\text { Localised at diagnosis } \\
\text { Metastasised at diagnosis }\end{array}$ & $\begin{array}{c}1 \text { (referent) } \\
1.48(1.22-1.80)\end{array}$ & $<0.001$ & $\begin{array}{c}1 \text { (referent) } \\
1.29(1.04-1.61)\end{array}$ & 0.020 \\
\hline \multicolumn{5}{|l|}{ Adjuvant chemotherapy } \\
\hline $\begin{array}{l}\text { Yes } \\
\text { No }\end{array}$ & $\begin{array}{c}1 \text { (referent) } \\
1.65(1.06-2.57)\end{array}$ & 0.028 & $\begin{array}{c}1 \text { (referent) } \\
1.17(0.74-1.87)\end{array}$ & 0.505 \\
\hline \multicolumn{5}{|l|}{ Adjuvant radiotherapy } \\
\hline $\begin{array}{l}\text { Yes } \\
\text { No }\end{array}$ & $\begin{array}{c}1 \text { (referent) } \\
1.10(0.69-1.75)\end{array}$ & 0.691 & $\begin{array}{c}1 \text { (referent) } \\
0.80(0.48-1.35)\end{array}$ & 0.406 \\
\hline \multicolumn{5}{|l|}{$\mathrm{N} / \mathrm{L}$ ratio 3.58} \\
\hline $\begin{array}{l}<3.58 \\
\geqslant 3.58 \\
\end{array}$ & $\begin{array}{c}1 \text { (referent) } \\
2.90(1.82-4.61) \\
\end{array}$ & $<0.001$ & $\begin{array}{c}1 \text { (referent) } \\
1.88(1.14-3.12) \\
\end{array}$ & 0.014 \\
\hline
\end{tabular}

A definitive explanation underlying these findings has not been clearly elucidated yet. Several possible reasons for the association between elevated N/L ratio and poor survival in cancer patients have been postulated. First, the high N/L ratio reflects an enhanced neutrophil response to tumours. In a mouse model, tumour cells secreted chemotactic cytokines, inflammatory proteins, and interleukins to recruit neutrophils to the tumour microenvironment (Ji et al, 2006). Neutrophils have been reported to stimulate tumour angiogenesis by producing proangiogenic factors, including growth factors, chemokines, and proteases, hence promoting tumour progression (Shamamian et al, 2001; Di Carlo et al, 2003; Schaider et al, 2003). Furthermore, neutrophils may suppress the immune system. They have been shown to inhibit the cytolytic activity of lymphocytes, natural killer cells, and activated T cells (Petrie et al, 1985; el-Hag and Clark, 1987; Shau and Kim, 1988). Second, elevated $\mathrm{N} / \mathrm{L}$ ratio reflects a relative lymphopenia. Lymphocytes are known to act as the host defense against tumour. They have a major role in cytotoxic cell death and cytokine production that inhibit proliferation and migration of tumour cells (Coussens and Werb, 2002; Mantovani et al, 2008). Systemic 


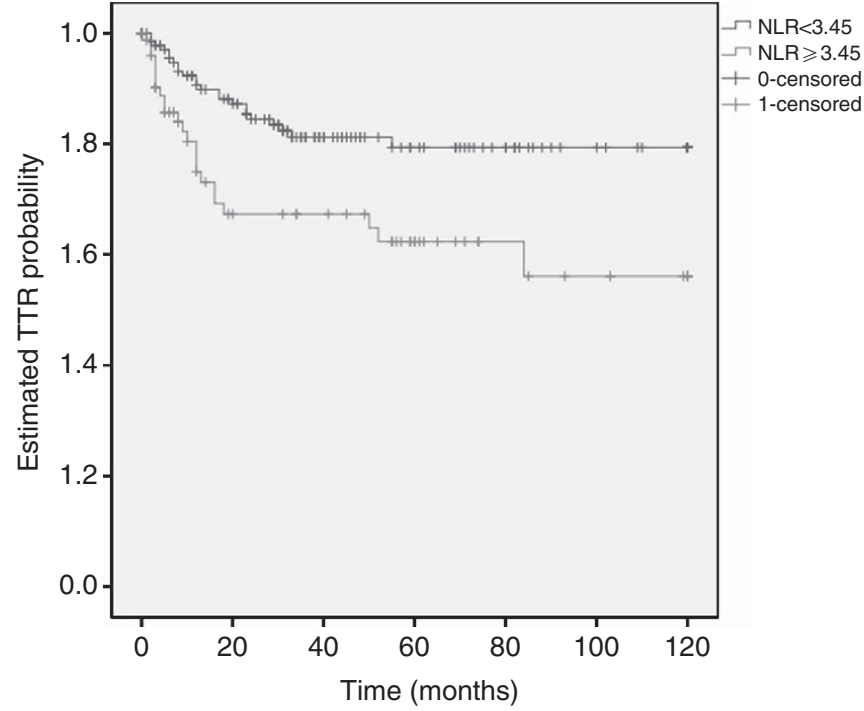

Figure 1. Univariate analysis of $N / L$ ratio and time to tumour recurrence. Abbreviations: NLR, N/L ratio; TTR, time to tumour recurrence.

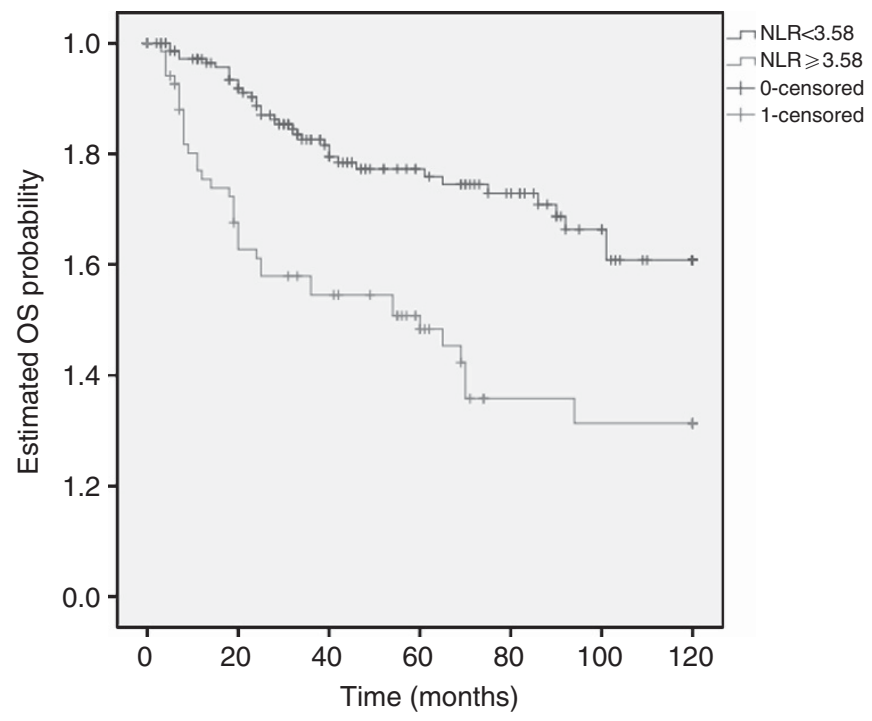

Figure 2. Univariate analysis of $\mathrm{N} / \mathrm{L}$ ratio and overall survival. Abbreviations: NLR, N/L ratio; OS, overall survival.

inflammation results in the secretion of inhibitory immunologic mediators, inducing immunosuppression due to impaired lymphocyte function (Mantovani et al, 2008). This process leads to a poorer lymphocyte-mediated antitumour cellular immune response, indicated by increased T8-suppressor lymphocytes and decreased T4-helper lymphocytes (Mantovani et al, 2008). The N/L ratio, in fact, reflects a balance between pro-tumour inflammatory status and antitumour immune status. This balance seems to be shifted in favour of pro-tumour inflammatory status in cancer patients with elevated N/L ratio and thus poor outcome.

In the present study, we also found a significant association between an elevated N/L ratio and tumour size of $\geqslant 5 \mathrm{~cm}$ and the presence of histopathological tumour necrosis. Since the elevated $\mathrm{N} / \mathrm{L}$ ratio and tumour necrosis were both significantly associated with clinical outcome, we hypothesise that the high N/L ratio may reflect the presence of tumour necrosis. In the subgroup analyses of the four major histologic entities, an elevated N/L ratio was associated with decreased clinical outcome in myxofibrosarcoma and liposarcoma. The lack of association between the N/L ratio and
Table 5. Univariate and multivariate analysis of association of prognostic factors and $N / L$ ratio with time to tumour recurrence in specific histologic tumour types

\begin{tabular}{|c|c|c|c|c|}
\hline \multirow[b]{2}{*}{ Parameter } & \multicolumn{2}{|c|}{ Univariate analysis } & \multicolumn{2}{|c|}{ Multivariate analysis } \\
\hline & $\begin{array}{c}\mathrm{HR} \\
(95 \% \mathrm{Cl})\end{array}$ & $\boldsymbol{P}$-value & $\begin{array}{c}\mathrm{HR} \\
(95 \% \mathrm{Cl})\end{array}$ & $\boldsymbol{P}$-value \\
\hline \multicolumn{5}{|c|}{ Myxofibrosarcoma } \\
\hline & $\begin{array}{c}1 \text { (referent) } \\
3.98(1.44-11.00)\end{array}$ & 0.008 & $\begin{array}{c}1 \text { (referent) } \\
2.51(0.74-8.50)\end{array}$ & 0.141 \\
\hline \multicolumn{5}{|c|}{ Liposarcoma } \\
\hline & $\begin{array}{c}1 \text { (referent) } \\
2.97(0.29-33.03)\end{array}$ & 0.375 & $\begin{array}{c}1 \text { (referent) } \\
4.88(0.12-201.66)\end{array}$ & 0.404 \\
\hline \multicolumn{5}{|c|}{ Leiomyosarcoma } \\
\hline & $\begin{array}{c}1 \text { (referent) } \\
1.76(0.38-8.09)\end{array}$ & 0.469 & $\begin{array}{c}1 \text { (referent) } \\
2.12(0.18-25.35)\end{array}$ & 0.553 \\
\hline \multicolumn{5}{|c|}{ Synovial sarcoma } \\
\hline & $\begin{array}{c}1 \text { (referent) } \\
5.97(0.68-52.20)\end{array}$ & 0.106 & $\begin{array}{c}1 \text { (referent) } \\
7.46(0.31-178.03)\end{array}$ & 0.214 \\
\hline Abbrev & fideno & $=\mathrm{haz}$ & $; N /$ & ohocyte. \\
\hline
\end{tabular}

Table 6. Univariate and multivariate analysis of association of prognostic factors and N/L ratio with overall survival in specific histologic tumour types

\begin{tabular}{|c|c|c|c|c|}
\hline & \multicolumn{2}{|c|}{ Univariate analysis } & \multicolumn{2}{|c|}{ Multivariate analysis } \\
\hline Parameter & $\mathrm{HR}(95 \% \mathrm{Cl})$ & $P$-value & $\mathrm{HR}(95 \% \mathrm{Cl})$ & $P$-value \\
\hline \multicolumn{5}{|c|}{ Myxofibrosarcoma } \\
\hline & $\begin{array}{c}1 \text { (referent) } \\
3.64(1.43-9.24)\end{array}$ & 0.007 & $\begin{array}{c}1 \text { (referent) } \\
1.52(0.53-4.36)\end{array}$ & 0.441 \\
\hline \multicolumn{5}{|c|}{ Liposarcoma } \\
\hline & $\begin{array}{c}1 \text { (referent) } \\
5.36(1.19-24.08)\end{array}$ & 0.028 & $\begin{array}{c}1 \text { (referent) } \\
16.60(1.78-154.62)\end{array}$ & 0.014 \\
\hline \multicolumn{5}{|c|}{ Leiomyosarcoma } \\
\hline & $\begin{array}{c}1 \text { (referent) } \\
2.60(0.92-7.31)\end{array}$ & 0.070 & $\begin{array}{c}1 \text { (referent) } \\
1.82(0.48-6.91)\end{array}$ & 0.381 \\
\hline \multicolumn{5}{|c|}{ Synovial sarcoma } \\
\hline & $\begin{array}{c}1 \text { (referent) } \\
3.79(0.92-5.66)\end{array}$ & 0.066 & $\begin{array}{c}1 \text { (referent) } \\
5.56(0.68-45.67)\end{array}$ & 0.110 \\
\hline
\end{tabular}

clinical outcome in leiomyosarcoma and synovial sarcoma may be due to the small sample size.

The strength of this study is definitely the large sample size and the long follow-up period. However, there are also some limitations, mostly arising from the retrospective study design and a mixture of various histologic subtypes of STS. Nevertheless, as STSs are rare and heterogenous tumours, pooling of different histologic subtypes by tumour grade is well established in studies on prognosis in patients suffering from STS. 
In conclusion, the presented results indicate that an elevated preoperative $\mathrm{N} / \mathrm{L}$ ratio in the peripheral blood is independently associated with poor clinical outcome in STS patients undergoing curative tumour resection. Validation studies or large scaled prospective studies are warranted to verify our findings.

\section{REFERENCES}

An X, Ding PR, Li YH, Wang FH, Shi YX, Wang ZQ, He YJ, Xu RH, Jiang WQ (2010) Elevated neutrophil to lymphocyte ratio predicts survival in advanced pancreatic cancer. Biomarkers 15: 516-522.

Borden EC, Baker LH, Bell RS, Bramwell V, Demetri GD, Eisenberg BL, Fletcher CD, Fletcher JA, Ladanyi M, Meltzer P, O'Sullivan B, Parkinson DR, Pisters PW, Saxman S, Singer S, Sundaram M, van Oosterom AT, Verweij J, Waalen J, Weiss SW, Brennan MF (2003) Soft tissue sarcomas of adults: state of the translational science. Clin Cancer Res 9: 1941-1956.

Chen Z, Gerhold-Ay A, Gebhard S, Boehm D, Solbach C, Lebrecht A, Battista M, Sicking I, Cotarelo C, Cadenas C, Marchan R, Stewart JD, Gehrmann M, Koelbl H, Hengstler JG, Schmidt M (2012) Immunoglobulin kappa C predicts overall survival in node-negative breast cancer. PLoS ONE 7: e44741.

Cho H, Hur HW, Kim SW, Kim SH, Kim JH, Kim YT, Lee K (2009) Pre-treatment neutrophil to lymphocyte ratio is elevated in epithelial ovarian cancer and predicts survival after treatment. Cancer Immunol Immunother 58: 15-23.

Clark EJ, Connor S, Taylor MA, Madhavan KK, Garden OJ, Parks RW (2007) Preoperative lymphocyte count as a prognostic factor in resected pancreatic ductal adenocarcinoma. HPB (Oxford) 9: 456-460.

Coindre JM (2006) Grading of soft tissue sarcomas: review and update. Arch Pathol Lab Med 130: 1448-1453.

Coussens LM, Werb Z (2002) Inflammation and cancer. Nature 420: 860-867.

Di Carlo E, Forni G, Musiani P (2003) Neutrophils in the antitumoral immune response. Chem Immunol Allergy 83: 182-203.

el-Hag A, Clark RA (1987) Immunosuppression by activated human neutrophils. Dependence on the myeloperoxidase system. J Immunol 139: 2406-2413.

Enneking WF, Spanier SS, Goodman MA (1980) A system for the surgical staging of musculoskeletal sarcoma. Clin Orthop Relat Res 106-120.

Fletcher CDM, Unni KK, Mertens F (2002) World Health Organization Classification of Tumours: Pathology and Genetics of Tumours of Soft Tissue and Bone 9-224. IARC Press: Lyon.

Gomez D, Farid S, Malik HZ, Young AL, Toogood GJ, Lodge JP, Prasad KR (2008) Preoperative neutrophil-to-lymphocyte ratio as a prognostic predictor after curative resection for hepatocellular carcinoma. World J Surg 32: 1757-1762.

Gousias K, Becker AJ, Simon M, Niehusmann P (2012) Nuclear karyopherin a2: a novel biomarker for infiltrative astrocytomas. J Neurooncol 109: 545-553.

Idowu OK, Ding Q, Taktak AF, Chandrasekar CR, Yin Q (2012) Clinical implication of pretreatment neutrophil to lymphocyte ratio in soft tissue sarcoma. Biomarkers 17: 539-544.

Jackson JR, Seed MP, Kircher CH, Willoughby DA, Winkler JD (1997) The codependence of angiogenesis and chronic inflammation. FASEB J 11: 457-465.

Jaiswal M, LaRusso NF, Burgart LJ, Gores GJ (2000) Inflammatory cytokines induce DNA damage and inhibit DNA repair in cholangiocarcinoma cells by a nitric oxide-dependent mechanism. Cancer Res 60: 184-190.

Ji H, Houghton AM, Mariani TJ, Perera S, Kim CB, Padera R, Tonon G, McNamara K, Marconcini LA, Hezel A, El-Bardeesy N, Bronson RT, Sugarbaker D, Maser RS, Shapiro SD, Wong KK (2006) K-ras activation generates an inflammatory response in lung tumors. Oncogene 25: 2105-2112.

Jilma B, Blann A, Pernerstorfer T, Stohlawetz P, Eichler HG, Vondrovec B, Amiral J, Richter V, Wagner OF (1999) Regulation of adhesion molecules during human endotoxemia. No acute effects of aspirin. Am J Respir Crit Care Med 159: 857-863.

Jung MR, Park YK, Jeong O, Seon JW, Ryu SY, Kim DY, Kim YJ (2011) Elevated preoperative neutrophil to lymphocyte ratio predicts poor survival following resection in late stage gastric cancer. J Surg Oncol 104: 504-510.

Kattan MW, Leung DH, Brennan MF (2002) Postoperative nomogram for 12year sarcoma-specific death. J Clin Oncol 20: 791-796.

Kim HS, Han KH, Chung HH, Kim JW, Park NH, Song YS, Kang SB (2010) Neutrophil to lymphocyte ratio for preoperative diagnosis of uterine sarcomas: a case-matched comparison. Eur J Surg Oncol 36: 691-698.

Lee YY, Choi CH, Kim HJ, Kim TJ, Lee JW, Lee JH, Bae DS, Kim BG (2012) Pretreatment neutrophil:lymphocyte ratio as a prognostic factor in cervical carcinoma. Anticancer Res 32: 1555-1561.

Liegl-Atzwanger B, Hofmann G, Leithner A, Beham A (2009) Undifferentiated high-grade pleomorphic sarcoma (UHPS): Diagnostic criteria, differential diagnosis, and treatment. An attempt to erasure the misnomer MFH. Eur Surg 41: 143-149.

Mallappa S, Sinha A, Gupta S, Chadwick S (2013) Preoperative neutrophil lymphocyte ratio greater than five is a prognostic factor for recurrent colorectal cancer. Colorectal Dis 15: 323-328.

Mantovani A, Allavena P, Sica A, Balkwill F (2008) Cancer-related inflammation. Nature 454: 436-444.

Petrie HT, Klassen LW, Kay HD (1985) Inhibition of human cytotoxic T lymphocyte activity in vitro by autologous peripheral blood granulocytes. $J$ Immunol 134: 230-234.

Sarraf KM, Belcher E, Raevsky E, Nicholson AG, Goldstraw P, Lim E (2009) Neutrophil/lymphocyte ratio and its association with survival after complete resection in non-small cell lung cancer. J Thorac Cardiovasc Surg 137: 425-428.

Schaider H, Oka M, Bogenrieder T, Nesbit M, Satyamoorthy K, Berking C, Matsushima K, Herlyn M (2003) Differential response of primary and metastatic melanomas to neutrophils attracted by IL-8. Int J Cancer 103: 335-343.

Shamamian P, Schwartz JD, Pocock BJ, Monea S, Whiting D, Marcus SG, Mignatti P (2001) Activation of progelatinase A (MMP-2) by neutrophil elastase, cathepsin G, and proteinase-3: a role for inflammatory cells in tumor invasion and angiogenesis. J Cell Physiol 189: 197-206.

Shau HY, Kim A (1988) Suppression of lymphokine-activated killer induction by neutrophils. J Immunol 141: 4395-4402.

Siegel R, Naishadham D, Jemal A (2012) Cancer statistics, 2012. CA Cancer J Clin 62: 10-29.

Suzuki S, Toyabe S, Moroda T, Tada T, Tsukahara A, Iiai T, Minagawa M, Maruyama S, Hatakeyama K, Endoh K, Abo T (1997) Circadian rhythm of leucocytes and lymphocytes subsets and its possible correlation with the function of the autonomic nervous system. Clin Exp Immunol 110: 500-508.

Teramukai S, Kitano T, Kishida Y, Kawahara M, Kubota K, Komuta K, Minato K, Mio T, Fujita Y, Yonei T, Nakano K, Tsuboi M, Shibata K, Furuse K, Fukushima M (2009) Pretreatment neutrophil count as an independent prognostic factor in advanced non-small-cell lung cancer: an analysis of Japan Multinational Trial Organisation LC00-03. Eur J Cancer 45: $1950-1958$.

Zhang H, Wang DW, Mahmoudi S, Adell G, Farnebo M, Sun XF (2012) WRAP53 is an independent prognostic factor in rectal cancer-a study of Swedish clinical trial of preoperative radiotherapy in rectal cancer patients. BMC Cancer 12: 294.

This work is published under the standard license to publish agreement. After 12 months the work will become freely available and the license terms will switch to a Creative Commons AttributionNonCommercial-Share Alike 3.0 Unported License. 